Article

\title{
The political economy of homeownership: a comparative analysis of homeownership ideology through party manifestos
}

\section{Sebastian Kohl ${ }^{1,2, *}$}

${ }^{1}$ Max Planck Institute for the Study of Societies, Paulstr. 3, 50676 Köln, Germany and ${ }^{2}$ Uppsala University, Sociology, Institute for Housing and Urban Research, Trädgårdsgatan 18, 75309 Uppsala, Sweden

\section{*Correspondence: kohl@mpifg.de}

\begin{abstract}
America's 'infatuation with homeownership' has been identified as one cause of the latest financial crisis. Based on codings of 1809 party manifestos in 19 countries since 1945 , this article addresses the question of where the political ideal to democratize homeownership came from. While conservative parties have defended homeownership across countries and time, centre-left parties have oscillated between a prohomeownership and a pro-rental position. The former occurs in Anglo-Saxon, Northern and Southern European countries, while the latter prevails among Germanspeaking countries. Beyond partisan effects, once a country has a majority of homeowners and parties defending homeownership, larger parties are more likely to support it. The extent of centre-left parties' support for homeownership is further associated with higher homeownership rates, more encouraging mortgage regimes and a bigger housing bubble burst after 2007. The ideational origins of the financialization of housing and private Keynesianism are, after all, not only conservative and market-liberal.
\end{abstract}

Key words: homeownership, comparative politics, political economy

JEL classification: homeownership, history of ideas, comparative politics

\section{Introduction}

In virtually all countries homeownership has increased over the last century. ${ }^{1}$ While rising economic incomes have been an important driver for this general tendency, most countries

1 A much longer earlier version of this text appeared as "A Small History of the Homeownership Ideal" in the MPIfG Discussion Paper series. I am obliged to Anna Riikka-Kauppinen for coding the Finnish manifestos. 
have also used policies supporting homeownership to influence tenure structure. This is based on the idea that democratized homeownership is beneficial for modern societies: the belief is that it creates more stable democracies, fosters individual virtues and counteracts revolutionary pressures through a broader distribution of wealth and better housing supply. However, countries differ in the extent to which they have made the homeownership ideal a dominant policy option. While the move towards property-owning democracies seems to have made homeownership an irreversible policy option almost everywhere, countries such as Germany or Switzerland with their traditionally larger shares of rental dwellings are still an exception to this rule. Recently, the idea of unlimited homeownership has also come under attack in many high-homeownership countries. The rise of mortgage debt as a byproduct of the homeownership ideal has led to the unstable regime of 'private Keynesianism' (Crouch, 2009). Moreover, governments supporting homeownership were accused of having contributed to the latest financial crisis by extending the dream of homeownership to those who simply did not have the means to realize that dream (Norberg, 2009). Indeed, countries and regions with the strongest homeownership increases during the pre-crisis years were also those with the highest mortgage debt levels, foreclosure rates and house-price volatility and deeper recessions (Field, 1992; Mian and Sufi, 2009; Brocker and Hanes, 2012; Jordà et al., 2016; Rünstler, 2016). The political preference of bringing homeownership to more people turned out to be another dangerous idea.

Despite their prominence, to date, homeownership ideology and policies have been neglected by comparative studies (Zavisca and Gerber, 2016). One reason for this is that housing and homeownership is still not treated as a stable pillar of the traditional welfare states, both in politics itself but also in comparative research. Although Esping-Andersen started his comparative work on the liberalization of housing policy and homeownership in Scandinavia (Esping-Andersen, 1985), the traditional welfare system based on income security became the cornerstone of comparative welfare studies. Another reason for the absence of homeownership in comparative studies is that many homeownership policies are part of the considerable 'hidden welfare state' (Howard, 1997), which is difficult to detect in comparisons as well as in public debates. Finally, indicators for housing structures, regulation, subsidies or policy positions still lack sufficient cross-country and over-time coverage to allow for the typical comparative research designs.

One central contribution of this article is therefore to provide new data on homeownership and policy positions on housing for 19 OECD countries between 1945 and 2013. Drawing on a new coding of housing policy content in 1809 party manifestos, this article offers a comparative history of ideas for the political ideal of homeownership. It answers the question as to which ideological, political and country-specific factors explain its variation across manifestos. As theoretical frameworks for the comparative explanation of housing policies are lacking, Section 2 develops such theory-informed expectations, based on the history of housing and analogies to similar policy fields, notably education. I expect parties' homeownership preferences to be determined by three kinds of factors: partisan ideology, politics and the wider structure of a country's political economy. Section 3 then presents the new content coding of housing policies, the descriptive and bivariate analysis, as well as multilevel analyses to explain the differential adoption of the homeownership ideal across parties and countries.

I find that housing policy is more likely to be proposed by centre-left parties, and only certain, notably Christian, conservative parties, as well as by larger parties in countries with more issue competition around housing. Although homeownership itself is generally a 
project of the political right, I find an interesting split among parties from the social democratic family across countries: social democracy in German-speaking countries, building on an urbanized tenant working class, a public rental alternative and strong tenancy laws, remained most hesitant about promoting broad homeownership. By contrast, in former Anglo-Saxon settler colonies, which started out with much higher homeownership rates in the first place, liberal and labour parties, pushed by competition for the median voter in two-party systems, made homeownership support their default housing policy right from the start. But also in the late-urbanizing, family-farm-based Scandinavian countries, social democracy favoured both cooperative and single-family house ownership, often in coalition with the equally ownership-affirmative farmer parties. In Latin social democracies, the competition from the radical left and the already high homeownership rates produced under conservative dictatorships shifted parties towards the homeownership ideal. Once a homeownership regime was in place, partisan ideology became almost unnecessary to maintain it. The need to win the support of the majority homeownership constituency and competition for the median voter from other parties proposing homeownership pushed particularly larger parties to also favour homeownership, regardless of other ideological commitments.

The discussion shows that the more, even centre-left, parties in a country have defended homeownership over the last few decades, the more it is associated with higher homeownership rates, a more lenient mortgage regime and a steeper drop in housing prices after 2007. By providing fresh data on a neglected policy field, this article reveals that the shift to more private mortgage indebtedness and 'infatuation with homeownership' (Norberg, 2009) before the Great Recession was not only a British-American story of market ideologues, but was observed in more countries and had a lot of party support, also on the political left.

\section{Theoretical background}

As fields of study, housing policy, not to mention homeownership preferences, have been even more neglected than other peripheral welfare areas such as, formerly, education policy (Ansell, 2008). It is, therefore, necessary for me to create some theoretical propositions concerning the factors determining homeownership preferences by drawing on general insights from historical housing studies. I will also borrow insights from other welfare domains, particularly education (Ansell, 2010; Busemeyer and Schlicht-Schmälzle, 2014), with which I find certain structural analogies.

A first group of factors determining homeownership preference is partisan and partisan ideology. Similar to education policy, it is not entirely clear whether homeownership is owned by the right or the left. Historically, the idea of bringing homeownership to the majority of the population is a typical conservative policy response and, in most countries, the first housing laws in support of homeownership before 1914 were inspired by the paternalist industrialist idea of buying worker support through the spread of homeownership (Pooley, 1992). Friedrich Engels' early critique of these conservative reform proposals is an important explanatory factor for socialists' early inaction in the field of homeownership and housing, more generally. More evidence for the conservative preference for homeownership can be found in historical studies showing conditional associations of regions with small landownership and conservative political outcomes, as in Marx's original claim about the smallholder vote for Napoleon III (Marx, 2007). While these studies concern periods in history 
when agrarian land ownership was more important than urban homeownership, many recent micro-level studies find that homeowners are more likely to vote for conservative parties (Ansell, 2014). If parties address these voter preferences, then one would expect that conservative parties are overall more likely to propose homeownership than other parties. A particular Scandinavian variety of this conservative preference lies in farmers' parties' democratic regrouping around independent land ownership. Catholic conservative parties on the continent, in turn, tended to adopt social policy suggestions from the Catholic Church, which, ever since the first social encyclicals in 1891, have proposed small land ownership as a social buffer (Guerrand, 1987).

While we can, therefore, expect a link between conservatism and homeownership, the stance of centre-left parties on housing and homeownership is far from clear-cut. Firstly, there is Engels' tradition of inaction or even outright opposition vis-à-vis homeownership, as formulated in the Housing Question in the 1870s (Engels, 1973). Secondly, reformoriented socialist and social democratic parties developed an alternative state-based housing provision model of state or municipal rentals and comprehensive tenant protection (security of tenure, rent controls). For the recently urbanized renting and working classes of the early 20th century, homeownership was simply out of reach in most cities. Moreover, homeownership subsidies are likely to be regressive, either because they redistribute to those who already have some equity or because mortgage or income tax exemption schemes reflect the progressivity of tax payments. Thus, from a socialist reform perspective, promoting homeownership runs counter to the worker constituency (Knüpfer, 1979). A third socialist tradition going back to the radical demands for agrarian egalitarianism and later closely associated with Proudhon is the defence of workers' small property as a security against capitalist labour markets and rent exploitation by landlords. The motives behind making the workers homeowners themselves can range from the idea of shielding them from marketsfor example, through cooperative ownership structures-and the idea of enabling workers to participate in the creation of capitalist wealth. Thus, overall, I expect centre-left parties to be divided over the homeownership question. Across countries, this divide could coincide with existing comparative accounts which find systematic differences between the centre-left parties of the Anglo-Saxon, Scandinavian, Germanic and Latin socialist movements (Keman, 2017).

A second group of factors determining homeownership positions lies more in the politics of housing than in partisan ideologies, that is, parties opt for homeownership for reasons of political strategy, not necessarily out of ideological conviction. One of my first expectations is thus that larger parties cannot really avoid addressing the considerable constituency of homeowners, even in countries where there is no homeowner majority. This effect should be particularly visible for European social democratic parties whose constituencies gradually moved from tenant to homeowner majorities as part of a general embourgeoisement of the working classes (Esping-Andersen, 1985) and social democracy's constituency shift to the middle classes (Häusermann 2018). According to the ISSP 2009 survey, for instance, the social democratic electorate comprised 49\% homeowners (mortgage-free plus mortgaged) in Germany, $43 \%$ in Austria and 29\% in Switzerland, while the majority of socialist voters in France $(76 \%)$, Labour voters in the UK $(64 \%)$, Democrats in USA $(65 \%)$ and social democrats in Sweden $(59 \%)$ were homeowners. Even in a low-homeownership country like Germany, the ALLBUS survey shows that the average homeownership rate of members of the social democratic party (SPD and Jusos) between 1980 and 1992 was 
$56 \%$, while the homeownership rate of union members increased from 51\% in 1994 to $65 \%$ in $2014 .^{2}$

A second politics-based expectation is that party competition might lead even ideologically uncommitted parties to imitate their political competitors and signal to their voters that they are not anti-homeownership. Again, this would be less driven by general ideological conviction and more about the politics of not allowing other parties to have an issue monopoly. A final expectation is that formerly incumbent parties are reluctant to oppose homeowners when running again for a new term, following the incumbency constraint hypothesis (Klingemann et al., 1995). All governments, even in tenancy-oriented countries like Germany, inherit ongoing programmes that subsidize homeownership, mostly through exemptions, but also through direct mortgage funds. Even if a party is not particularly committed to homeownership as a form of tenure, it will be more difficult for them to opt out of these commitments rooted in the status quo.

A third and final group of factors determining homeownership policies are structures of the political economy. Perhaps most obviously, existing homeownership levels or recent increases create larger constituencies of homeowners that particularly large parties need to address. As home-owning voters usually comprise families and tend to have higher voter turnout and political activity (André et al., 2017), it is impossible for parties to ignore them, once the median voter becomes an owner-occupier. In the available ISSP surveys between 1985 and 2006 , from over $50 \%$ to over $80 \%$ of those surveyed say that the government definitely or probably should provide for decent housing (own calculations). Another structural influence is the housing and house price cycle: in periods of rising house prices, support for homeowners is both more necessary and more in line with the expectations of the large number of voters climbing up the housing ladder. Keeping homeowner subsidies flowing can even become an issue of macroeconomic stability, as homes purchased in times of houseprice-mortgage-debt spirals are bought on the premise of continuously rising prices. Once the house price bubble bursts, foreclosed homeowners need help, but the frenzy of homeownership politics appears less opportune. Closely related to this, economic growth allows governments to make homeownership promises, while periods of economic crisis make lowcost rentals a necessity. Finally, following the literature that finds a trade-off between housing and general welfare, one can expect less of a need for parties to promote homeownership if there is a well-developed welfare state, particularly in the domain of public pensions.

In summary, whether homeownership policy propositions became a political option may be rooted in ideological party struggles, may depend more strategically on the politics of housing or can be driven by the general political economy of housing. The following section will turn to historical party manifestos to explore the determinants of the political homeownership ideal.

\section{Political career of homeownership through party manifestos post 1945}

Pushed by post-Second World War housing shortages, housing became an established policy field in Western democracies. Barely mentioned in political party manifestos before 1945, after the war, it became a standard repertoire of party positions. While housing studies

2 In the data from both of these surveys, the overall number of homeowners is slightly inflated, probably due to a middle-class bias in the survey design. 
ignored the comparative potential of manifestos so far, the political science literature around the Comparative Party Manifesto Project (CMP) ignored housing, largely due to lacking content codes (Volkens et al., 2015a). The CMP generally offers content codings of quasisentences ${ }^{3}$ on the salience of political pro and contra positions in 56 categories for Western democracies covering each election year since 1945 (1920). The categories refer to general political leanings (e.g., pro-welfare, pro-Keynesianism) rather than individual policy fields. Thus, housing and homeownership are not among the 56 variables, but quasi-sentences with housing content have generally been coded as 'pro-welfare' or 'free market economy'.

I, therefore, returned to the original CMP text corpus, added missing documents from original sources ${ }^{4}$ as far as possible and identified housing-specific content. In more recent manifestos, housing policy has an easily identifiable section of its own and for each respective language the terms 'house/housing, home, own, rent' are sufficient to identify this section. ${ }^{5}$ For many older manifestos, particularly the ones with bad or entirely without character recognition, the housing-policy suggestions needed to be manually identified. ${ }^{6}$ Once they had been identified, I manually coded five new content variables, namely whether a party defends homeownership, state-supported rental housing, or rent restrictions, or is anti-public housing, and whether a party mentioned any of these housing issues or not, using the following coding rules:

(1) Housing: If the other four housing policies are mentioned, if concrete policy recommendations are made that concern more than just marginal groups (handicapped, old people, migrants)

(2) Pro_homeownership: If the party defends subsidies for homeowners, if it intends to spread ownership among broad parts of the population, even reaching all and lower strata, if it wants to improve mortgage credit access for many or help foreclosure victims, if it promotes the sale of public housing or cooperative units to sitting tenants, if house, land and mortgage prices and not rent levels are the main problem

(3) Pro_rental: If the party promotes object-related subsidies for non-profit rental housing, state or cooperative housing, if it wants the state to take on the problem of rental housing construction, if it promotes rental housing beyond just a residual group, ${ }^{7}$ if it voices a preference for state-support for rental tenure

3 A quasi-sentence is the smallest parts of a sentence in which political positions can be identified.

4 For Austria see Berchthold (1967), for Canada see Carrigan (1968) and Birch et al. (2016), for Denmark see Danmarkshistorien (2016). KB (2017), for France (Sciences-Po library), for Germany see Treue (1988) and Mommsen (1960), for the Netherlands see DNPP (2016), for Norway see NSD (2016), for Sweden see Misgeld (2001), and SND (2017), for the UK see Dale (2000a, 2000c, 2000b), for the USA see Wooley and Peters (2016).

5 Relevant search terms in other languages are: 'bolig*, hjem, eie*, hus, leidighet,' 'propri*, quartiere, *fitto, locatione, abitazion*, casa, edilizia,' 'bostad, ägande*, hyres*, egna, hem, hus,' 'bolig, lejlig*, ejer*, ejendomm*,' 'Wohn*, Miet*, Eigen*, Heim,' 'propri*, vivienda, renta, alojamiento, alquil*", 'habitaço $\tilde{0}^{*}$, alug*, propri*,' 'habitation, propr*, loyer, maison,' 'won*, koopwoning, eigen, huur, volkshuis*, eengezin*', and 'koti, asunto, vuokra.'

6 This restriction also prohibits automated content analysis or dictionary-based searches.

7 There are also next to no parties denying at least minimal support for housing and the rental tenure. Theoretically, I therefore follow Kemeny (1981) and do not include cases where the rental tenure is only considered as a very residual housing form. 
(4) Rent_restriction: If the party is against free market rents, if it promotes rent freezes or caps on rent prices, if it is against rent usury

(5) Anti_public: If the party is against state intervention in housing, if it promotes the retreat of the state from housing policies, in general or from object-based subsidies, in particular, if it is against state-subsidized non-profit associations, if it supports residualist state housing policy

I coded manifestos from 19 OECD countries since 1945 (for USA since 1920). Southern European countries enter the corpus with the transition to democracy in the 1970 s. ${ }^{8}$ Eastern Europe has been excluded as the years before 1990 are obviously missing and homeownership questions were of a different nature in the transition economies. I chose to code only the presence $(=1)$ or absence $(=0)$ of policy positions categorically and not the salience in terms of the relative share of quasi-sentences in a document. Housing often follows a general critique of the salience approach (Gemenis, 2013, p. 5), in that positions are either defended or not defended. A more technical reason for categorical coding is that, as earlier manifestos are missing in the database, the exact division of many documents into quasi-sentences is not known. To evaluate a party's commitment to defending homeownership, I will, therefore, rely on the more qualitative assessment presented in Section 4 rather than inferring from relative frequencies counted. I coded only four substantive housing policy variables because homeownership is my main interest and because qualitative studies of housing suspect a party cleavage line over the issues mentioned. Unfortunately, more detailed policy propositions would have had too low coverage across time and countries. It would have been interesting to include variables such as support for housing savings versus mortgage payment tax deductions or support for single-family houses versus other architectonic forms, but this was not feasible. Coverage of the fine difference between more market-conform types of homeownership and forms with anti-market features would also have been unequal. The risk of confusing silence on these specific issues with an opposition position would have been too high.

Even though they are currently used in political science (Franzmann, 2009), for instance for successfully predicting government budget choices (Hofferbert and Klingemann, 1990), party manifestos are of course very particular speech acts. They may not represent a party's general outlook because that party may only be using them for political gain in the competition against other parties, they might represent a vague internal party consensus, they mostly contain only broad world views and only positive rather than negative policy statements, and they might differ from later coalition programmes and policy statements made within the legislative cycle (Seeger, 1995). They are also not informative about any monetary commitment from the parties in support of the statements they make. They do, however, mark important public statements, for which parties can be held responsible and which often represent the broader ideological outlook. If a party really wants to make something its cause, it will mention it, and if a party is clearly not in favour of something, it will not mention or even oppose it. In the housing case, only the stance against public housing and state intervention occurs with some frequency as a negative stance. In turn, homeownership is only

8 Greece and Iceland are missing due to language barriers. I coded manifestos myself with the exception of Finland where I relied on an external coder who I instructed with the help of the above coding scheme. I cross-checked the results with existing secondary literature as a robustness check. General knowledge of the countries' housing literature acted as validity check. 
Table 1 Coverage of country-years and means of housing positions in manifestos

\begin{tabular}{|c|c|c|c|c|c|c|c|c|}
\hline Country & Years & Manifestos & $\begin{array}{l}\text { With } \\
\text { housing } \\
\text { content }\end{array}$ & $\begin{array}{l}\text { Number } \\
\text { of } \\
\text { elections }\end{array}$ & $\begin{array}{l}\text { Pro- } \\
\text { homeownership }\end{array}$ & $\begin{array}{l}\text { Pro- } \\
\text { rental }\end{array}$ & Antisocial & $\begin{array}{l}\text { Rent } \\
\text { restrictions }\end{array}$ \\
\hline Australia & 1946-2013 & 98 & 76 & 27 & 0.95 & 0.26 & 0.01 & 0.04 \\
\hline Austria & 1949-2008 & 69 & 50 & 19 & 0.56 & 0.48 & 0.20 & 0.36 \\
\hline Belgium & 1946-2010 & 157 & 118 & 21 & 0.81 & 0.66 & 0.05 & 0.09 \\
\hline Canada & 1945-2011 & 89 & 72 & 22 & 0.63 & 0.67 & 0.00 & 0.06 \\
\hline Denmark & 1945-2011 & 175 & 108 & 21 & 0.50 & 0.44 & 0.20 & 0.10 \\
\hline Finland & 1945-2011 & 106 & 69 & 19 & 0.61 & 0.62 & 0.00 & 0.35 \\
\hline France & 1946-2012 & 74 & 61 & 17 & 0.61 & 0.70 & 0.15 & 0.26 \\
\hline Germany & 1949-2013 & 83 & 69 & 18 & 0.62 & 0.61 & 0.22 & 0.42 \\
\hline Great Britain & 1945-2010 & 62 & 60 & 18 & 0.88 & 0.77 & 0.17 & 0.22 \\
\hline Ireland & 1957-2011 & 69 & 64 & 16 & 0.98 & 0.38 & 0.00 & 0.05 \\
\hline Italy & 1946-2013 & 115 & 55 & 17 & 0.80 & 0.62 & 0.13 & 0.04 \\
\hline The Netherlands & 1946-2012 & 124 & 118 & 21 & 0.71 & 0.67 & 0.19 & 0.04 \\
\hline New Zealand & 1946-2011 & 88 & 70 & 23 & 0.96 & 0.37 & 0.07 & 0.04 \\
\hline Norway & 1945-2009 & 110 & 106 & 17 & 0.92 & 0.38 & 0.16 & 0.06 \\
\hline Portugal & 1975-2009 & 59 & 44 & 13 & 0.39 & 0.89 & 0.05 & 0.14 \\
\hline Spain & 1977-2011 & 73 & 64 & 11 & 0.83 & 0.92 & 0.02 & 0.06 \\
\hline Sweden & 1944-2010 & 116 & 73 & 21 & 0.56 & 0.44 & 0.21 & 0.19 \\
\hline Switzerland & 1947-2011 & 94 & 59 & 17 & 0.64 & 0.46 & 0.08 & 0.24 \\
\hline USA & 1920-2012 & 48 & 41 & 24 & 0.85 & 0.32 & 0.20 & 0.07 \\
\hline
\end{tabular}

Source: Own compilation.

very rarely opposed in Green parties', even more rarely in socialist parties' manifestos. There was, therefore, no need to code the negative stance on homeownership. Table 1 summarizes the country-year coverage and descriptive statistics by country. ${ }^{9}$

Of the 2183 party manifestos in the 19 countries, 372 documents are missing. Missings are particularly from the 1950s (50\% are before 1979) and particularly entire elections in Denmark, Italy and Switzerland. ${ }^{10}$ Fortunately, the missings in most other cases predominantly concern small parties (median of $4.41 \%$ vote share), niche or regional parties. Nevertheless, 22 of the total 372 elections have manifestos for parties garnering $<50 \%$ of the votes. The appendix analyses missings more systematically and one robustness test takes this issue into account.

Of the remaining 1809 documents, 430 do not mention any of the four housing policy propositions as content. With only $47 \%$, Italy has the lowest percentage of manifestos with housing content and the Anglo-Saxon countries have the highest. Among manifestos with housing content, $73 \%$ favour homeownership, the remainder does not mention it (but propose at least one other housing policy). In $55 \%$ of manifestos support for rental housing is mentioned, in $14 \%$ the preference is for rent restrictions and in $11 \%$ opposition to state housing intervention is expressed.

9 The data are provided on the author's website.

10 Missings relative to the party coverage of the 2015a CMP dataset, which itself does not systematically register many smaller parties, but at least all parties entering parliament. 
Across time and parties, homeownership support is highest in the Anglo-Saxon countries but also Norway with up to $100 \%$ of manifestos favouring homeownership and it is lowest in central European countries and Portugal. Rental housing support, by contrast, is lowest in Anglo-Saxon countries, though not Britain, and highest in the Southern European high-homeownership countries, where the incessant call for more rental housing is apparently incompatible with actual housing reality. The demand for rent restrictions is highest in German-speaking countries and lowest in English-speaking ones, as is the preference for cutting back on state housing intervention. Since these two policy options are rather marginal and also for reasons of space, I will focus on the dominant homeownership preferences.

The correlation between pro-homeownership and pro-rental housing (or pro-rent restriction) is $r=-0.31$ (or -0.30 ), while it is almost zero between pro-homeownership and antipublic housing. Homeownership and policies favouring tenants (either through state support for rental construction or rent-price restrictions) thus describe cleavage lines across all countries. The imperfect correlation, however, also shows that the policy positions are not mutually exclusive. The zero correlation between homeownership and the market-liberal stance against state housing intervention shows a certain independence of the market liberals with regard to the other two positions. In the ideological landscape of Western parties, the homeownership ideal occupies a rather conservative position. The highest positive correlations are with 'free enterprise', 'incentives' $(0.19$ and 0.23$)$ and pro-military spending $(0.17)$, and the highest negative correlations are with 'social justice' $(-0.23)$ and 'nationalization' $(-0.17)$. The correlations with the CMP's composite ideological indices are similar: right/ left scale $(0.22)$, pro-welfare scale $(-0.23)$ and market-economy $(0.18)$. These bivariate findings suggest that the thesis about the trade-off between welfare and homeownership on the party-discursive level is correct: the more parties defend welfare policies, the less they defend homeownership.

The right-left division of the homeownership position can also be determined from its support in the different party families that the 270 different parties in the sample are grouped into. The pro-homeownership stance is defended in $94 \%$ of conservative party and $93 \%$ of Christian democratic manifestos, followed by $85 \%$ of agrarian party and $81 \%$ of liberal party manifestos. At the lower end are socialist parties with $38 \%$ and green parties with $18 \% .{ }^{11}$ Social democratic parties are in between with a slightly below-average $67 \%$, while socialists and social democrats have the highest variance of positions across countries and time, even more than the often heterogeneous special issue or nationalist parties. The picture for the rental housing support is roughly the reverse: socialist parties almost always defend rental housing, followed by green parties ( $84 \%$ of their manifestos), and social democratic parties (77\%). But Christian democratic parties also still defend this option in almost half of all manifestos (49\%), while conservative, liberal, agrarian and nationalist parties are at the lower end with around $25 \% .^{12}$

On the aggregate level, homeownership positions do not follow a simple linear time trend. On the level of individual parties, however, some discontinuities can be observed. The

11 If they showed any interest at all in housing beyond narrow ecological topics, they opposed the neo-liberal housing tendencies of the established parties. Often with a constituency of urban tenants, they argued for dense cities of rental housing, stronger state activity in housing and against the environmentally destructive suburban sprawl of single-family houses.

12 Also see Figure 1 on the party-family rankings. 
sequence of homeownership position spells can be constructed for the 223 parties, with a range of 9-74 election points (Gabadinho et al., 2009). ${ }^{13}$ After deleting missings, parties can either be assigned the status of defending homeownership or not and if they have one status in one election, the party can either keep the same status or transition to the other at the next election. Of all parties not defending homeownership at a given election, $41 \%$ switched to a pro-homeownership stance at the next election, the remainder still did not support homeownership. By contrast, the transition rate for parties starting with a defence of homeownership position at a given election to continuing to be pro-homeownership at the following election is $88 \%$. Thus, once a homeownership position has been reached, it is rarely abandoned, while non-homeownership positions turned more frequently into homeownership positions. A look at the individual party position sequences reveals that while conservative parties' defence of homeownership was quite stable over time, it is the centre-left parties that tended to shift to homeownership positions over time. For support for rental housing, the picture is similar: once a party defends rental housing, that position is continued at the following election (78\%), while the transition to rental support occurs in only $26 \%$ of cases. Here it is the centre-left parties that remain stationary, while conservative parties had only some pro-rental spells in their sequence during moments of crisis (post-war or post-2007).

To explain the determinants of homeownership positions in a multivariate context with reference to the theoretical expectations from Section 2, I proceed in two steps: firstly and preliminarily, I explain why party manifestos mention housing policy at all, as those not mentioning housing policy are by definition not defending homeownership. Second and more importantly, I explain why manifestos defend homeownership, assuming that they mention housing policy in the manifesto. As a modelling technique, I estimate two multilevel logistic regression models with the mention of housing and the pro-homeownership position as a binary dependent variable for each model. I use logistic models because the dependent variable is binary; I use multilevel models because the data are hierarchically structured and therefore not independent. Manifestos are generally nested in parties which are part of party families, but they are also nested in particular election contexts. Moreover, both parties and elections are also nested in countries. In the following multilevel models, I opt for both a country-level and a party-family level as higher levels in which manifestos are nested. There are both empirical and theoretical reasons for this: empirically, both of these levels significantly lower the information criterion values (AIC) when added to null models, more so than adding elections as a level. Adding elections as a third level does not enhance the information degree of the models and generates convergence problems. Instead, I will model the time context by using periodical dummy variables. My theoretical reasoning for this course of action, in line with the theory section above, is that both country and party-related factors are more important than election-specific questions. I opt for party families and not individual parties as a level to reduce the complexity of 223 different, at times historically discontinuous, parties. The country level is chosen beyond the partisan level to include the structural background of national political economies.

As main explanatory and control variables, I also follow Section 2 as a guide for operationalizations. The document length (number of quasi-sentences) serves as a general control (Hansen, 2008). As first substantive variables for partisan ideology, I use the CMP's party family variable and the right-left scale (RILE), which is positive when a manifesto tends 
Table 2 Regression on the mention of housing

\begin{tabular}{|c|c|c|c|c|}
\hline & \multicolumn{4}{|c|}{ Housing on manifesto agenda } \\
\hline & Model (1) & Model (2) & Model (3) & Model (4) \\
\hline Document length & $1.157 * * *(0.152)$ & $0.942 * * *(0.145)$ & $1.091 * *(0.153)$ & $0.922 * *(0.141)$ \\
\hline Left-right (RILE) & $-0.162 *(0.072)$ & $-0.145(0.075)$ & $-0.210 *(0.079)$ & $-0.175 *(0.077)$ \\
\hline Party competition & & $0.622 * * *(0.083)$ & & $0.621 * *(0.082)$ \\
\hline Vote share & & $0.230 *(0.093)$ & & $0.189 *(0.094)$ \\
\hline Lag incumbency & & $0.066(0.074)$ & & \\
\hline Homeownership & & & $0.056(0.149)$ & $-0.065(0.091)$ \\
\hline GDP p.c. & & & $-0.377(0.222)$ & $-0.216(0.178)$ \\
\hline House prices & & & $0.260(0.148)$ & $0.182(0.125)$ \\
\hline GDP p.c. growth rate & & & & $0.019(0.102)$ \\
\hline Homeownership growth & & & & $0.160 *(0.070)$ \\
\hline House price growth & & & & $0.032(0.078)$ \\
\hline $\begin{array}{l}\text { Period } 1920-1955 \text { (reference } \\
\quad \text { period } 1990-2006)\end{array}$ & $0.603 *(0.230)$ & $0.689 *(0.274)$ & $0.123(0.555)$ & $-0.123(0.500)$ \\
\hline Period 1956-1975 & $1.046 * *(0.186)$ & $0.956 * *(0.190)$ & $0.792 *(0.380)$ & $0.690 *(0.338)$ \\
\hline Period 1976-1990 & $0.720 * * *(0.178)$ & $0.614 * * *(0.178)$ & $0.573 *(0.238)$ & $0.427(0.226)$ \\
\hline Period 2007-2015 & $-0.154(0.205)$ & $-0.139(0.226)$ & $-0.208(0.258)$ & $-0.118(0.248)$ \\
\hline Constant & $1.003 * * *(0.244)$ & $1.073 * * *(0.184)$ & $1.192 * *(0.292)$ & $1.205 * *(0.227)$ \\
\hline Observations & 1803 & 1615 & 1636 & 1589 \\
\hline Log Likelihood & -839.588 & -727.511 & -755.778 & -716.840 \\
\hline Akaike information criteria & 1697.175 & 1479.022 & 1535.557 & 1467.680 \\
\hline Bayesian information criteria & 1746.650 & 1543.667 & 1600.357 & 1558.984 \\
\hline
\end{tabular}

Note: ${ }^{*} P<0.05 ; * P<0.01 ; * * P<0.001$.

more to the right. Second, as variables describing the politics, I use a party's vote share, its status of incumbency (versus opposition) in the previous legislative term and, to operationalize party competition, I use the sum of party support for homeownership in a country. Third, as variables for the economic structure, I use the level of homeownership, GDP per capita, house prices and OECD social expenditure per GDP at a given election, or, alternatively, the growth rate over the four legislative years preceding the election. ${ }^{14}$ All variables are standardized using the grand mean. Finally, I add time period dummies because elections are not annual events and not synchronized across countries. Following periodizations in the housing literature (Bengtsson et al., 2006), I use the post-war era until 1955, the postwar construction boom until 1975, the post-oil crisis downturn, the housing boom period of 1990-2006 and the Great Recession period thereafter. Table 2 shows the first regression on the mention of housing on a party's manifesto agenda.

14 House price data are from Jordà et al. (2017), Knoll et al. (2015), Kohl (2018), from the OECD for Ireland and New Zealand, Statistics Austria for Austria. Real GDP per capita with purchasingpower parity are taken from the extended Maddison-Project (2013). Election and party variables come from the ParlGov data provided by Döring and Manow (2010). The OECD data are taken from the OECD Social expenditure database after 1980 and before 1980 from Lindert (2004). The interpolated homeownership data are from Kohl (2017). 
The models here and below, all nested in party families and countries, start from the variables on the manifesto and partisan level to successively introduce the politics and economic background variables. In the first model, the party family random intercepts (not shown) reveal that although socialist and social democratic parties are most likely to mention housing in their manifestos, they are closely followed by conservative and Christian democratic parties. Housing thus shares features with other welfare domains, even though it is not an exclusive reserve of the left. The RILE scale, which also takes into account ideological changes within a party (family) and time period, supports this observation as right-wing manifestos are less likely to mention housing. Moving one standard deviation to the right on this scale makes mentioning housing 1.17 times less likely. Document length is a particularly important control variable for the specialized housing policy field, with longer documents being more likely to contain housing issues per se. The early post-war manifestos, those published during uncertain times for polities in economic or constitutional crises, usually have other priorities than housing policy. The time dummies suggest a generally declining focus on housing since the war. Manifestos between 1956 and 1975, for instance, were 2.6 times more likely to mention housing than those from 1990 to 2006. The second model introduces the politics variables of political parties: the larger a party and the more housing is mentioned across parties in a country, the greater the probability of the party also addressing housing, whereas smaller and special issue parties can afford to not mention this particular policy field. Whether a party was incumbent or in opposition in the preceding term is without effect. ${ }^{15}$ The third model introduces the structural background variables at their election-year levels. Here, housing appears more on the manifesto agenda when GDP p.c. is low and house prices are high. In the complete Model 4 which additionally introduces the growth rate of these variables across the preceding 4 years, they remain significant, with homeownership growth making housing policy mentions more likely. Overall, this regression shows that mentioning housing issues per se in manifestos is similar to other welfare policies, in that it is more of an issue of the left, dependent on the general and housingspecific business cycle and prone to strategic politics.

More importantly in the present context, the second regression displayed in Table 3 focuses on those manifestos that do mention housing in order to explain what makes them support homeownership as a policy option.

The order of models is the same as before: again, the document length control is important, as longer manifestos tend to propose homeownership. Over time, the prohomeownership stance started to become important after the end of the reconstruction boom in the 1970s only to decline again after the Great Recession. The long housing boom from the 1990s onward was thus accompanied by homeownership promises in manifestos, which appeared 2.4 times less after 2007 when parties rediscovered the rental housing support alternative during the crisis. Contrary to the case of general housing policies, it is parties on the right which are more likely to argue for homeownership. An interaction with the period dummies (not shown) reveals this to be constant through time. This effect is also

15 It is insignificant throughout and dropped hereafter and below to avoid missing cases. The structural variables for the period before 1980 are unavailable for Austria, Ireland and New Zealand, which explains the lower number of cases. The OECD social expenditure data are not available for the 1950s. 
Table 3 Multilevel regression on pro-homeownership

\begin{tabular}{|c|c|c|c|c|}
\hline & \multicolumn{4}{|c|}{ Pro-homeownership positions } \\
\hline & Model (1) & Model (2) & Model (3) & Model (4) \\
\hline Document length & $0.353 * * *(0.106)$ & $0.265^{*}(0.108)$ & $0.246^{*}(0.113)$ & $0.168(0.107)$ \\
\hline Left-right (RILE) & $0.164(0.101)$ & $0.203(0.107)$ & $0.175(0.112)$ & $0.276^{*}(0.118)$ \\
\hline $\begin{array}{l}\text { Period } 1920-1955 \text { (reference } \\
\quad \text { period } 1990-2006)\end{array}$ & $-0.739 *(0.289)$ & $-0.964 *(0.326)$ & $-0.372(0.678)$ & \\
\hline Period 1956-1975 & $-0.148(0.234)$ & $-0.340(0.247)$ & $0.070(0.472)$ & $0.093(0.502)$ \\
\hline Period 1976-1990 & $0.422(0.233)$ & $0.389(0.245)$ & $0.542(0.312)$ & $0.590(0.313)$ \\
\hline Period 2007-2015 & $-0.761 *(0.262)$ & $-0.912 *(0.289)$ & $-0.801 *(0.311)$ & $-0.903 *(0.328)$ \\
\hline Lag incumbency & & $0.044(0.093)$ & & \\
\hline Party competition & & $1.087 * * *(0.123)$ & & $1.017 * * *(0.137)$ \\
\hline Vote share & & $0.261 *(0.116)$ & & $0.432 *(0.133)$ \\
\hline Homeownership & & & $0.669 * * *(0.203)$ & $0.238(0.135)$ \\
\hline House prices & & & $0.167(0.171)$ & $0.268(0.157)$ \\
\hline GDP p.c. & & & $-0.308(0.263)$ & $-0.162(0.230)$ \\
\hline Homeownership growth & & & & $0.019(0.105)$ \\
\hline House price growth & & & & $-0.173(0.119)$ \\
\hline GDP p.c. growth & & & & $0.089(0.198)$ \\
\hline Social expenditure/GDP & & & & $0.115(0.143)$ \\
\hline Constant & $1.513 *(0.536)$ & $1.730 * * *(0.432)$ & $1.383^{*}(0.546)$ & $1.466 *(0.447)$ \\
\hline Observations & 1371 & 1240 & 1244 & 1056 \\
\hline Log Likelihood & -602.157 & -515.855 & -541.351 & -432.419 \\
\hline Akaike Inf. Crit. & 1222.314 & 1055.709 & 1106.702 & 898.837 \\
\hline Bayesian Inf. Crit. & 1269.324 & 1117.184 & 1168.215 & 983.195 \\
\hline
\end{tabular}

Note: $* P<0.05 ; * P<0.01 ; * * P<0.001$.

reflected in the different probabilities with which different party families defended homeownership as displayed in Figure $1 .{ }^{16}$

Christian democratic parties are in the lead, followed by conservative parties and parties of the political right, whereas centre-left and green parties are most likely to not argue for homeownership. On the level of countries, the probabilities are shown in Figure 2. Most Anglo-Saxon countries, along with Norway, lead the ranking, while German-speaking and some Scandinavian countries show least support for homeownership. An interaction (not shown) of countries with a dummy for the social democratic party family reveals that social democracies' position on homeownership is moderated by different country effects: compared to Germany, other German-speaking and some Scandinavian countries have less social democratic homeownership support, while Anglo-Saxon and Southern European countries tend to have more.

The second model in Table 3 introduces politics variables. Whereas former incumbent or opposition parties do not differ significantly, once again, it is the larger parties and those in

16 Based on a null model with party families and countries as upper levels. Controlling for country effects, the probability of defending homeownership (instead of not defending it) can be calculated as the logit transformation of the fixed intercept plus the country-specific random intercept. Figure 2 shows the same probabilities just for countries controlling for party families. 


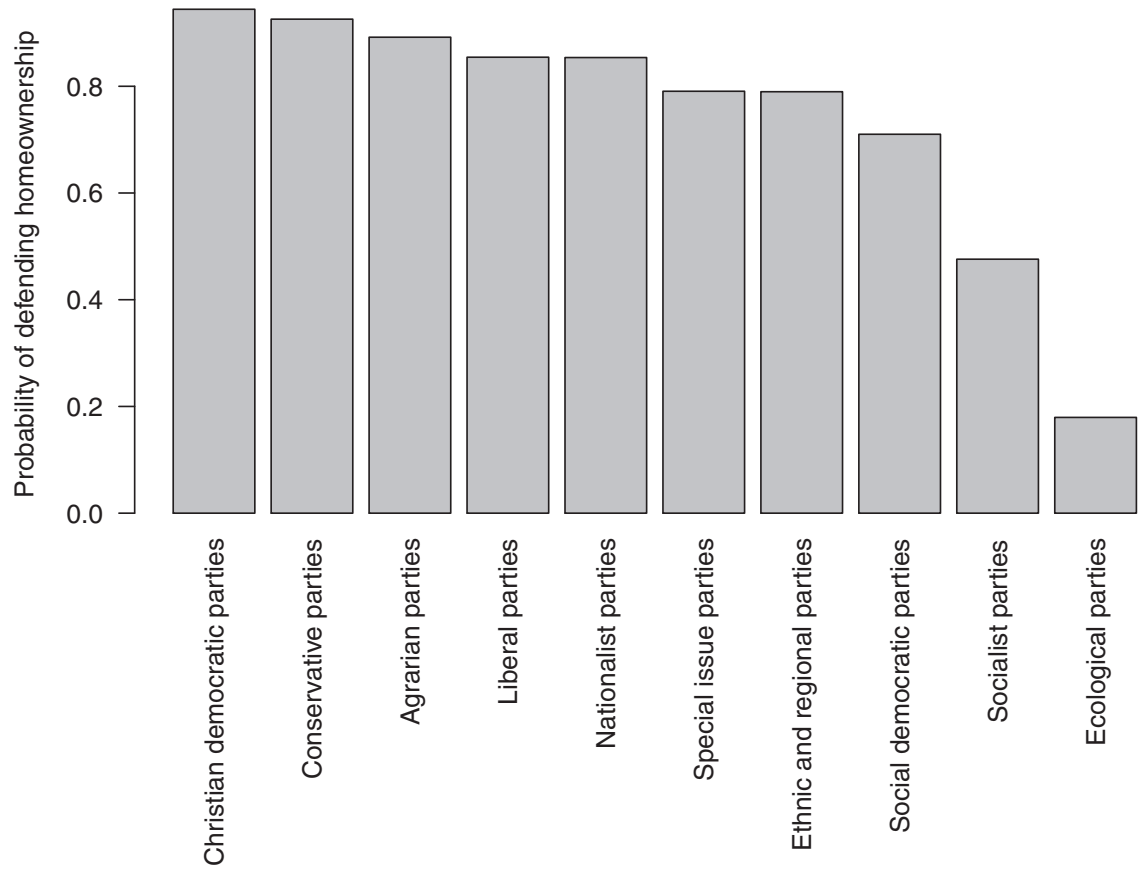

Figure 1 Party-family-specific random intercepts.

Source: Own calculations.

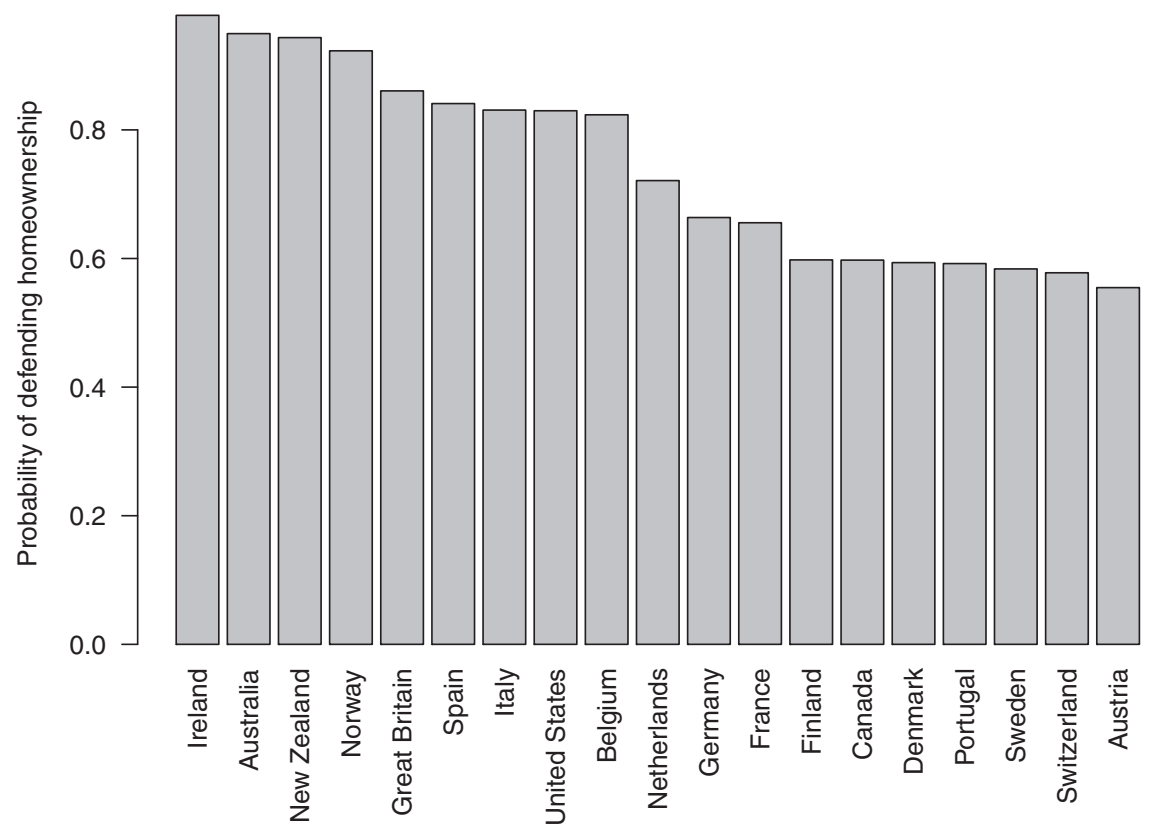

Figure 2 Country-specific random intercepts.

Source: Own calculations. 
more intense competition around the homeownership issue that are more likely to also argue for homeownership. The following models introduce the level and change of economic background variables. The housing or business cycle leave homeownership support untouched, whereas higher homeownership levels in a country make pro-homeownership stances more likely: an increase of one standard deviation makes the pro-homeownership stance almost twice as likely. Previous GDP growth increases the likelihood of pro-homeownership manifestos, while a country's welfare state level does not have a significant effect.

I conducted three robustness tests. Firstly, I reduced the sample by all manifestos presented at elections where the vote share is $<50 \%(70 \%)$ due to missing manifesto data. Secondly, I reduced the sample by all parties below the $5 \%$ vote threshold to control for possible effects of parties with less political relevance. The lower number of cases in these alternative models, however, still leave the substantive effects intact. Thirdly, I estimated logistic regressions with country, party-family and time dummies instead of multilevel models because this is often considered an alternative strategy to account for the dependencies in the data structure as they rule out any unobserved differences of the higher levels. Moreover, the multilevel model could have the problem of too few cases on the upper levels. As reported in the Appendix Tables A1-A3, the main substantive effects of the above multilevel models are robust.

\section{Variation in centre-left support for homeownership and its consequences}

What emerges from these analyses is that in the political economy of housing and homeownership, general economic background factors, parties' political strategies, but above all party ideology, all play a role in explaining variation in homeownership positions. Housing is a policy field that larger parties cannot neglect and, once more parties in a country take up housing and homeownership as an issue, other parties are pressured to follow suit. They are more influenced by growing homeownership rates or high levels of homeownership, while the housing cycle plays a less important role. Besides party choice for homeownership as driven by political strategy or the expediency of the (housing) economy, political parties also follow more general ideologies when it comes to housing and homeownership. Like other welfare policies, housing in general is more a project of the political left, whereas the homeownership issue tends to be owned by the political right. There is barely a single manifesto on the right that does not mention homeownership. On the left, however, there is substantial variation, with important nuances and country specificities meriting further qualitative discussion.

In line with my initial expectation, conservative and particularly Catholic parties are ideologically most committed to homeownership and have most to say about it in their manifestos. The recurrent arguments in favour of homeownership include its beneficial effects for families and stable citizenship and its contribution to opposing communism. Some conservative parties such as in the UK, New Zealand or Norway also make use of the idea of a 'property-owning democracy'. The Social Credit Party of Canada went as far as claiming in 1962 that: 'Social Credit recognizes the family as the basic unit of society and regards the sanctity of the home as fundamental to the preservation of Christian civilization', where home refers to 'owner-occupied' housing financed by a state-controlled credit scheme. But 
also Nordic farmer parties seldom leave homeownership unmentioned as an instrument for opposing urbanization.

While Christian democracy has consistently pursued a mission to create more homeowning families, they also differ from other conservative parties in their more frequent commitment to a rental alternative. Given the prominence of Christian democratic parties in postwar governments when social housing in rental form reconstructed many European cities, it was often these parties rather than the social democrats that built a system of housing welfare (Van Kersbergen, 1995). In this respect, housing is similar to other pillars of the welfare state in countries like Germany (Schulz, 1988), Italy (Pilat, 2014), Austria, the Netherlands, France's fourth Republic, Italy and—with nuances due to its strong homeownership tradition (Goossens, 1982)-Belgium. Christian conservatives could count on their own network of housing associations as pillars of their policies either in favour of family ownership or of workers' rental housing (Stieber, 1998, p. 28). The conservative side could also rely on Catholic and Protestant housing associations as well as organizations of the natalist movement in support of housing for large families. Centre-left parties, in turn, aligned with housing associations linked to the unions, with tenant organizations, the cooperative movement, or the municipal governments of towns with a large worker population. Conservative parties in Anglo-Saxon countries, by contrast, considered state rental housing for more than just residual groups a post-war emergency measure and centre-left parties, even if they were pro-rental, could not count on the network of non-profit associations available to housing policy in Europe.

This lack of support from a broader public housing movement is one background condition for the housing positions of centre-left parties in Anglo-Saxon countries. Having briefly toyed with public rental housing in the Great Depression and post-war era, they soon focused predominantly on a democratization of homeownership. Thus, the New Zealand Labour Party promised in 1966 that 'A LABOUR Government will continue Labour's traditional policy of assisting those who wish to own their own homes, building State owned houses for those unable to contemplate homeownership, and encouraging local bodies to provide community owned housing.' The Liberal Party of Canada promised in 1979 'to bring ownership within the reach of an increased number of Canadians', while the US Democrats of the Great Society era stated in 1968 that 'the objective is to enable the poor to own their own homes. ${ }^{17}$ In Great Britain, Labour had traditionally been the ally of council housing, but also favoured the sale of council houses to sitting tenants as early as the 1950s. Labour countered the Conservatives' 'property-owning democracy' in 1959 with the promise that they would 'help people buy their own homes and. . ensure an adequate supply of decent houses to let at a fair rent'. In 1970, the British Labour Party proclaimed that 'Home ownership will be further encouraged. For the first time in our history, 50 per cent of the nation's homes are now owner-occupied. We believe that this proportion will rise and should continue to rise. We shall extend the system of 100 per cent mortgages.' And, in 1980, the Australian Labour Party campaigned with 'The great Australian dream of owning your own home is now out of reach of most families.'

This strongly contrasts with the social democrats in German-speaking countries, which have tended not to mention homeownership at all or, if they have, then not as a core policy position. The issue is virtually absent from their Swiss and Austrian manifestos and, though

17 In Canada, third parties on the left, by contrast, mostly opposed the strong homeownership focus. 
appearing as an add-on to public housing in about half of German manifestos, it remains a marginal issue. The German SPD was particularly slow in addressing the petty propertyowning bourgeoisie: Engels had already ridiculed the French socialists for their accommodation strategy towards small-holding peasants in the 1890s and bringing homeownership to workers continued to be decried as the bad Proudhonian way (Knüpfer, 1979). While the SPD began to, at least pragmatically, mention property owners by the end of the 1920s, this did not erase the petty bourgeois and farmers' fears of being expropriated (Lösche and Franz, 1992). Only with its transformation into a popular party and a gradual embourgeoisement of its constituency in the 1950s did the SPD also agree to state support for homeownership. But it was the SPD's opposition on the national level and particularly on the level of the state governments in Germany's federal system which prevented the stronghold of Christian democrats in the ministry of construction in the 1950s and 1960s from creating an anti-communist Western Republic of homeowners (Schulz, 1988). While the Austrian SPÖ had turned to the small property owners much earlier, Austrian conservatives, for instance, were still complaining in 1983 about socialists' attempts to boycott any advantageous tax treatment of homeownership. In the same year, German social democrats criticized the regressive effects of homeownership subsidies. Besides the German-speaking social democracies, the Danish, Swedish and Dutch social democrats have traditionally been the most committed to housing in the form of non-profit controlled rentals, but these parties took a much more favourable stance towards homeownership over the course of time (Aalbers, 2004). Dutch social democrats first mentioned their goal of helping even lower income strata to buy their own apartments in 1977, proclaiming again in 1986: 'People with modest income wishing to become homeowners must be supported. They should be given priority in the attribution of contingents of newly constructed units for ownership.' In Sweden, the social democrats changed their pre-war small ownership position and engaged in massive state support for public rental housing units. From the 1970s, however, the discourse of a 'neutrality of tenure' made homeownership a real alternative (Lundqvist, 1986) to the previously privileged rental housing.

In the other Scandinavian countries, the 'Proudhonian' socialist alternative of workers' small ownership persisted. The social democrats in Finland (Ruonavaara, 1999), Norway (Annaniassen, 2006) and Iceland (Sveinsson, 2004) became the prime advocates of small ownership for everyone. But the tradition of small ownership as the defence of cooperative ownership also persisted in Sweden and Denmark. In post-war Denmark, social democrats coalesced with the conservatives to support a huge mortgage program in favour of singlefamily house buyers (Esping-Andersen, 1985, p. 180), which even led to a rise in votes for the radical centre-left Socialist People's Party and created a social democratic homeowners' constituency (Esping-Andersen, 1978). Many of the Proudhonian homeownership policies were characterized by specific non-market provisions, such as the price control of state-subsidized units at resale or the state's right to be the primary purchaser at resale. An important motivation behind these socialist homeownership policies in Norway was to free workers from exploitation in the private rental market (Sørvoll, 2013). Thus, the Norwegian Labour Party proposed in 1945: 'The state and credit institutions will together facilitate housing credit for all strata of society. [...] All Nordic working men and women, even those with the lowest income, shall get a real house at a price they can afford. ${ }^{18}$ Over the course of time, 
and not least through the interest of cooperative homeowners in realizing their market values, the Proudhonian strings attached to these forms of non-market property were substantially loosened and differences between cooperative and private property began to disappear.

Also, in Latin social democracies, there was a trend towards supporting homeownership among socialist parties, even if this was in no way homogeneous. In part this resulted from a worker cooperative tradition, such as in Spain (Arias González, 2003, p. 223), while in France or Italy, socialist parties faced competition from Communist alternatives on the left (Manow, 2015) and had a difficult time positioning themselves between Communist calls for Soviet-like nationalization of all housing and the clear ownership focus of the strong governing Christian Democrats. Thus, socialists and unions in Italy supported the creation of laws favouring (condominium) ownership, such as the case popolari in 1903 (Piccinato, 1988) or the INA Casa of the conservative Fanfani Plan in the 1960 (Ginsborg, 2003). In France, all major housing laws supporting homeownership, from the pre-1914 laws to the Loucheur law in 1928, were passed in parliament thanks to the socialist vote (Raymond, 1966, p. 202; Sowa, 1991, p. 23). In Belgium, the idea of owner-occupied small houses in garden cities was also defended by the socialist party, if not unanimously (Goossens, 1982, chapter 2.2), while in Portugal, centre-left parties were responsible for the new housing ministry after the revolution in the 1970s, making easy credit access the new democratic policy (Ferreira, 2011).

Thus, while, overall, conservative parties agreed on the benefits of homeownership, the centre-left parties differed most across countries with those cross-country differences reflecting the existing varieties of social democracy. With the necessary abstraction, social democracy in German-speaking countries, building on an urbanized tenant working class, a public rental alternative and strong tenancy laws, remained most hesitant about broad homeownership promotion. By contrast, in former Anglo-Saxon settler colonies, which started from much higher homeownership rates in the first place, the liberal and Labour parties, driven by competition for the median voter in two-party systems, made homeownership support their default housing policy right from the start. But also in the late-urbanizing, family-farmbased Scandinavian countries social democracy favoured both cooperative and single-family house ownership, often in coalition with the equally ownership-affirmative farmer parties. In Latin social democracies, the competition from the radical left and the already high homeownership rates produced under conservative dictatorships shifted parties towards the homeownership ideal. ${ }^{19}$

As in virtually all party systems, centre-left parties play an important role in the formation of political opinions and even government and their stance on homeownership reflects how strongly this idea is generally politically accepted and achievable. The percentage of centre-left party ${ }^{20}$ manifestos that are pro-homeownership can thus be used as a proxy for

19 In the political economy of conservative dictatorships, construction policies favouring middle-class homeownership are a recurrent phenomenon because they boost the domestic economy, do not need FDI, stabilize pro-incumbent constituencies and reflect the ideological family orientation of dictators. This is observed in the Southern European, German-Austrian, but also Latin American dictatorships, see Bodenschatz et al. (2015).

20 I use the CMP family of 'social democratic parties,' which refers to the dominant labour parties or the main liberal party. 
how broadly the homeownership ideal has also conquered the political left which, prior to the 2008 housing bubble burst, had often been in competition with their political opponents to target an increasing number of potential homeowners with subsidies, particularly in twoparty systems (Schelkle, 2012). Unsurprisingly, therefore, the mean percentage of prohomeownership manifestos since 1945 produces a positive correlation with countries' mean homeownership rates since 1945 . The precise causal order of this link is difficult to establish and the merely promissory status of party manifestos does not even make them the most appropriate source. Elsewhere, the impact of centre-left party positions on homeownership levels and growth is shown to be significant in distributed lag models, controlling for typical homeownership explaining factors (Kohl, 2018).

The manifestos do not systematically cover the precise political instruments through which parties aim to achieve homeownership. Again, more qualitative readings allow more nuance here. Homeownership policies can thus be divided into state-orchestrated or 'socialized' models of homeownership (Norris, 2016), where state institutions act as direct mortgage lenders or even as builders, most notably in Norway, Iceland or Ireland. A second policy instrument for homeownership prevails in weak welfare states, where parties are in favour of homeownership in principle, but lack the means to do more than permit the family-based informal promotion of this form of tenure. In Portugal, for instance, housing policies and homeownership, in particular, are among the least mentioned, even though parties in this high-homeownership country have been reported to be strong supporters of homeownership (Ferreira, 2011). The third and most widespread model is state support for of private mortgage institutions, by offering saving bonuses to building societies, but, more frequently, by providing incentives to take on mortgage debt: through the creation of secondary mortgage markets, interest rate deregulation, the extension of loan-to-value ratios and the tax exemptions on mortgage payments.

Policy instruments increasing mortgage indebtedness were also among the prime recommendations proposed by centre-left parties, which even competed with conservative parties in making mortgage credit more accessible to lower-income households. As early as 1964, for instance, long before Thatcher's right-to-buy policy, the British Labour Party demanded that the government 'help the owner-occupiers by providing 100 per cent mortgages' and US Democrats proposed in 1984 that 'we must maintain and expand the flow of mortgage capital. The American dream of home ownership will fall beyond the reach of this generation and future ones if government fails to help attract new sources of capital for housing.' Making mortgage credit affordable to working men and women and lower-income groups is a common theme throughout the centre-left manifestos in countries with or aspiring to high or higher homeownership rates. Even communist parties, such as in Norway in 1957 or in Spain in 1982, joined the call to extend low-interest, long-term credit lines to workers. Mortgage market deregulation, which started in the 1980s, was thus not exclusively a conservative project, but also found support among centre-left parties, though this was moderated by country contexts. There is thus an association between countries with stronger support for homeownership among centre-left parties and a more lenient mortgage regulation policy: again associating the across-time average of pro-homeownership positions of centre-left parties with Fuller's index of mortgage credit regulation (measuring the degree of mortgage-debt encouraging regulation by the 2000s) results in a significant correlation of 0.52 (Fuller, 2015). Alternatively, the average of the centre-left party homeownership position has a significantly positive effect when regressed on the mortgage debt per GDP variable 


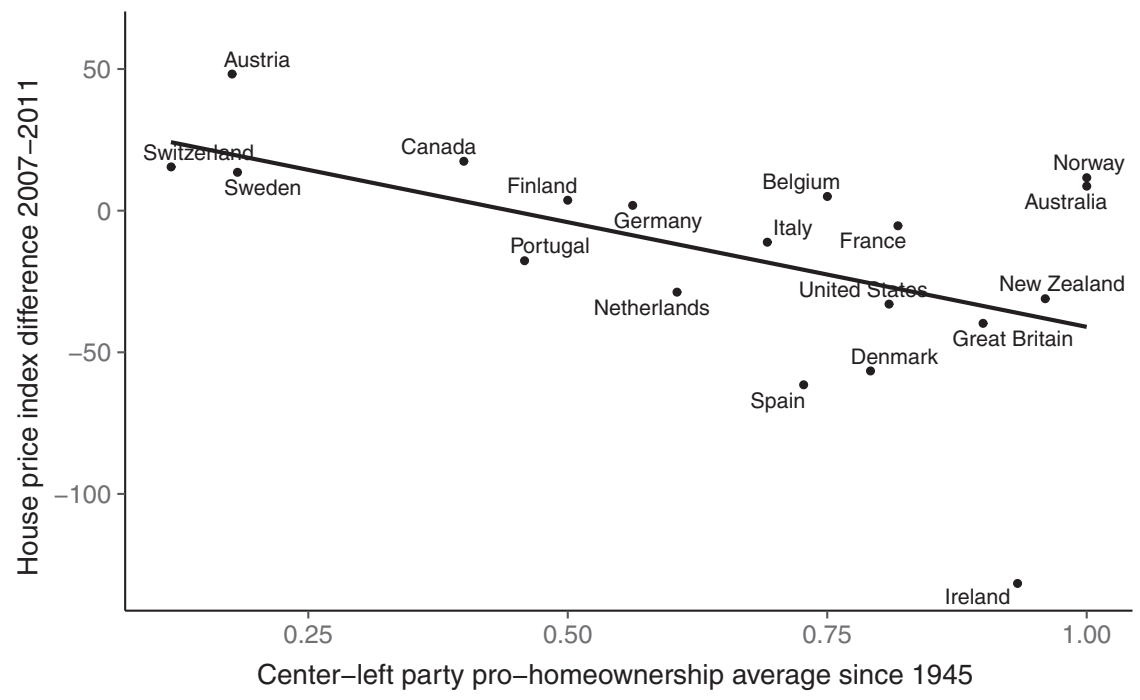

Figure 3 House price burst post-2007 and center-left parties' pro-homeownership stances.

Note: Linear regression line with $95 \%$ confidence interval.

from the Macrohistory Database (Jordà et al., 2017), controlling for country and year dummies.

The country-specific diffusion of the homeownership ideal among the political left also sheds light on the latest housing market burst, approximated by the house price index difference between 2011 and 2007. The 'infatuation with homeownership' has sometimes been cited as a main driver not only behind the rise in homeownership rates, but also the 2007 burst of the housing bubble (Norberg, 2009). Figure 3 thus shows that the more the social democratic parties historically defended homeownership, the steeper a country's house price fall after the housing market crashed, with Ireland being even worse off than its high level of centre-left homeownership support would have led us to expect and with Norway and Australia being even better off. The correlation of -0.62 is significant at the 0.001 level and still holds at the 0.1 level when controlling for countries' mean homeownership rate since 1945 , based on the 19 cases to which this single-event analysis is restricted.

\section{Conclusion}

The 'unacknowledged policy regime' of extending household debt for homeownership that is said to have led to the financial crisis has also been described as privatized Keynesianism (Crouch, 2009). Following the demise of traditional publicly financed demand management, conservative political currents are said to have brought about the market-based creation of demand through private household indebtedness (Streeck, 2013). Housing and housing policies, with the predominance of private mortgages in all household debt, is probably the most important policy field for this regime change diagnosis. In this standard account, it was predominantly neo-liberal currents, a pro-market ideology and conservative parties that featured as the most important actors in the making of privatized Keynesianism. 
This article enriches this standard account by starting from the policy domain that perhaps characterizes the new regime most: housing and the neglected history of the homeownership ideal, whose political project arguably represented the origins of the 'great mortgaging' and was far from being an issue cherished by conservative parties or neo-liberal ideologues alone. In fact, a glance into its history through party manifestos reveals that, whereas conservative parties and particularly Christian Democrats were consistent defenders of the homeownership ideal, a relatively large number of parties on the left of the political spectrum had also favoured homeownership since the beginning or have moved to this position over time (depending on the country context). Following existing accounts of the varieties of social democracy, one can broadly distinguish between three types of social democracy: the more homeownership-restrictive Germanic model, the homeownershipsupportive Latin and Anglo-Saxon models, and-with the proviso of internal heterogeneity and the cooperative tradition-the Scandinavian models. The more important homeownership became for the partisan ideology of centre-left parties, the more countries' housing regimes tended to rely on homeownership as the dominant form of tenure, with more mortgage-debt encouraging regulation and stronger house-price decline in the Great Recession. But, from a certain point onwards, party ideology of whatever denomination becomes dispensable. In countries with homeowner majorities, larger parties cannot afford to ignore this important constituency. Once more parties take up the homeownership issue, party competition, in turn, pushes even more parties to also defend homeownership as the preferred form of tenure. In addition, the importance of house prices for pension politics and macroeconomic stability makes it difficult for any party to withdraw mortgage support for existing and aspiring homeowners. Thus, even if the homeownership ideal started out as a project of ideologically committed parties, the political economy of homeownership tended to generate more allies in support of this ideal, a lock-in which only the recent house price crash could resolve.

In terms of the initial hypotheses, housing thus follows other welfare domains in that parties of the political left are more likely to mention it, whereas it is the opposite for homeownership, albeit with considerable country differences. Apart from partisan ideology, however, the 'politics' hypothesis is also valid, as larger parties subject to more political competition are more likely to support homeownership. Finally, the political economy structures also influence the overall degree of homeownership support in manifestos, albeit to a lesser extent than expected.

The cross-country analysis of housing politics and homeownership politics in particular is a virtually unexplored field, despite its importance as a domain of welfare and Keynesian construction politics. As a weak pillar of the welfare state, it shares some interesting features with the politics of education: it is virtually impossible for parties to be against more education and more homeownership; both policy fields have received growing attention from parties; centre-left parties are divided over whether to consider education or homeownership as a means of advancing the workers and making them participate in the capitalist game of human and housing capital, respectively, or whether to consider the two as perpetuators of the status quo, with both subsidy structures redistributing in a regressive way. Moreover, both policy fields have turned from public to more private sources of funding, particularly in countries with homeownership and private school traditions, and have thus contributed to a growth of household indebtedness with ensuing inflationary problems. Finally, the differences between countries in both policy fields do not perfectly coincide with the existing welfare typologies built on the income-maintenance core of welfare states. 


\section{References}

Aalbers, M. B. (2004) 'Promoting Home Ownership in a Social-Rented City: Policies, Practices and Pitfalls', Housing Studies, 19, 483-495.

André, S., Dewilde, C. and Luijkx, R. (2017) 'The Tenure Gap in Electoral Participation: Instrumental Motivation or Selection Bias? Comparing Homeowners and Tenants across Four Housing Regimes', International Journal of Comparative Sociology, 58, 241-265.

Annaniassen, E. (2006) 'Varför så olika? Nordisk bostadspolitik i jämförande historiskt ljus'. In Bengtsson Bo et al. (eds) Norge - Det Socialdemokratiska Ägarlandet, Malmö, Égalité, pp. 195-276.

Ansell, B. W. (2008) 'University Challenges: Explaining Institutional Change in Higher Education', World Politics, 60, 189-230.

Ansell, B. W. (2010) From the Ballot to the Blackboard: The Redistributive Political Economy of Education, Cambridge, Cambridge University Press.

Ansell, B. W. (2014) 'The Political Economy of Ownership: Housing Markets and the Welfare State', American Political Science Review, 108, 383-402.

Arias González, L. (2003) El Socialismo y La Vivienda Obrera En España: La Cooperativa Socialista De Casas Baratas «Pablo Iglesias»1926-1939, Salamanca, Ed. Univ. de Salamanca.

Bengtsson, B., Annaniassen, E., Jensen, L., Ruonavaara, H. and Sveinsson, J. R. (2006) Varför Så Olika? Nordisk Bostadspolitik i Jämförande Historiskt Ljus, Malmö, Égalité.

Berchthold, K. (1967) Österreichische Parteiprogramme 1866-1966, Wien, Verlag für Geschichte und Politik.

Birch, L., Jean, C., Imbeau, L. M., Jacob, Steve and Pétry, F. (2016) accessed at www.poltext.org (With the financial support of the Fonds de recherche du Québec-Sociéte et culture (FRQSC)).

Bodenschatz, H., Piero, S. and Guerra, M. W. (2015) Urbanism and Dictatorship: A European Perspective, Basel, Birkhäuser.

Brocker, M. and Hanes, C. (2012) The 1920s American Real Estate Boom and the Downturn of the Great Depression: Evidence from City Cross Sections, Cambridge, MA: NBER Working Paper.

Busemeyer, M. R. and Schlicht-Schmälzle, R. (2014) 'Partisan Power, Economic Coordination and Variations in Vocational Training Systems in Europe', European Journal of Industrial Relations, 20, 55.

Carrigan, D. O. (1968) Canadian Party Platforms 1867-1968, Urbana, IL, University of Illinois Press.

Crouch, C. (2009) 'Privatised Keynesianism: An Unacknowledged Policy Regime', The British Journal of Politics \& International Relations, 11, 382-399.

Dale, I. (2000a) Liberal Party Election Manifestos 1900-1997, London, Politico's.

Dale, I. (2000b) Labour Party Election Manifestos 1900-1997, London, Politico's.

Dale, I. (2000c) Conservative Party Election Manifestos 1900-1997, London, Politico's.

Danmarkshistorien (2016) 'Partiprogram' (Aarhus Universitet), Aarhus, accessed at http://dan markshistorien.dk/forside/ on July 29, 2017.

DNPP (2016) Documentatiecentrum Nederlandse Politieke Partijen, Groningen, Rijksuniversiteit.

Döring, H. and Manow, P. (2010) 'Parliament and Government Composition Database (ParlGov)', An Infrastructure for Empirical Information on Parties, Elections and Governments in Modern Democracies. Version, 10, 6.

Engels, F. (1973) 'Zur Wohnungsfrage'. MEW 18, Edited by the International Marx-Engels Foundation, Amsterdam, Berlin, Dietz Verlag, pp. 209-287.

Esping-Andersen, G. (1978) 'Social Class, Social Democracy, and the State: Party Policy and Party Decomposition in Denmark and Sweden', Comparative Politics, 11, 42-58. 
Esping-Andersen, G. (1985), Politics against Markets. The Social Democratic Road to Power, Princeton, Princeton University Press.

Ferreira, A. F. (2011) Anos 1970/1980 - Do Fundo De Fomento Da Habitação Ao Instituto Nacional De Habitação 1950-80, Instituto da Habitação e da Renovação Urbana Lisboa, accessed at http://fonsecaferreira.pt/discurso-directo.html on July 29, 2017.

Field, A. J. (1992) 'Uncontrolled Land Development and the Duration of the Depression in the United States', The Journal of Economic History, 52, 785.

Franzmann, S. (2009) The Change of Ideology: How the Left-Right Cleavage Transforms into Issue Competition. An Analysis of Party Systems using Party Manifesto Data, University of Cologne, Dissertation, Köln.

Fuller, G. W. (2015) 'Who’s Borrowing? Credit Encouragement Vs. Credit Mitigation in National Financial Systems', Politics \& Society, 43, 241-268.

Gabadinho, A. et al. (2009) Mining Sequence Data in $R$ with the TraMineR Package: A Users Guide for Version 1.2, Geneva, University of Geneva.

Gemenis, K. (2013) 'What to Do (and Not to Do) with the Comparative Manifestos Project Data', Political Studies, 61, 3-23.

Ginsborg, P. (2003) A History of Contemporary Italy: Society and Politics, 1943-1988, London, Palgrave Macmillan.

Goossens, L. (1982) Het Sociaal Huisvestingsbeleid In België: Een Histor.-Sciolog. Analyse Van De Maatschappelijke Probleembehandeling Op Het Gebied Van Het Wonen, Dissertation, Leuven.

Guerrand, R.-H. (1987) Propriétaires Et Locataires. Les Origines Du Logement Social En France: 1850-1914, Paris, Éditions Quintette.

Hansen, M. E. (2008) 'Back to the Archives? A Critique of the Danish Part of the Manifesto Dataset', Scandinavian Political Studies, 31, 201-216.

Häusermann, S. (2018) 'Social Democracy and the Welfare State in Context: The Conditioning Effect of Institutional Legacies and Party Competition'. In Manow, P., Palier, B., and Schwander, H. (eds) Welfare Democracies and Party Politics: Explaining Electoral Dynamics in Times of Changing Welfare Capitalism, Oxford, Oxford University Press, pp. 150-170.

Hofferbert, R. I. and Klingemann, H-D. (1990) 'The Policy Impact of Party Programmes and Government Declarations in the Federal Republic of Germany', European Journal of Political Research, 18, 277-304.

Howard, C. (1997) The Hidden Welfare State: Tax Expenditures and Social Policy in the United States, Princeton, Princeton University Press.

Jordà, Ò., Schularick, M. and Taylor, A. M. (2016) 'The Great Mortgaging: Housing Finance, Crises and Business Cycles', Economic Policy, 31, 107-152.

Jordà, Ò., Schularick, M. and Taylor, A. M. (2017) 'Macrofinancial History and the New Business Cycle Facts'. In Eichenbaum Martin and Parker Jonathan A. (eds) NBER Macroeconomics Annual 2016, Vol. 31, Chicago, Chicago University Press, pp. 1-55.

KB (2017) 'Det Kongelige Bibliotek', København, accessed at http://www.kb.dk/ on July 29, 2017.

Keman, H. (2017) Social Democracy. A Comparative Account of the Left-Wing Party Family, London, Routledge.

Kemeny, J. (1981) The Myth of Home Ownership. Private versus Public Choices in Housing Tenure, London, Routledge.

Klingemann, H-D., Hofferbert, R. I. and Budge, I. (1995) Parties, Policies and Democracy, Boulder, Westview.

Knoll, K., Moritz, S. and Steger, T. (2015) No Price Like Home: Global House Prices, 1870-2012, Centre for Economic Policy Research Discussion Paper No. 10166.

Knüpfer, U. (1979) Die Wohnungspolitik Der SPD Zwischen 1900 Und 1933. Sozialdemokratische Kommunalpolitik Auf Dem Wege Zur "Verwaltung Der Bürgerlichen 
Gesellschaft”. Unter Bessonderer Berücksichtigung Des Ruhrgebietes, Bochum, Magisterarbeit.

Kohl, S. (2017) Homeownership, Renting and Society: Historical and Comparative Perspectives, London, Routledge.

Kohl, S. (2018) 'More Mortgages, More Homes? the Effect of Housing Financialization on Homeownership in Historical Perspective', Politics \& Society, 46, 177-203.

Lindert, P. H. (2004) Growing Public: Social Spending and Economic Growth since the Eighteenth Century, Cambridge, Cambridge University Press.

Lösche, P. and Franz, W. (1992) Die SPD. Klassenpartei-Volkspartei-Quotenpartei. Zur Entwicklung Der Sozialdemokratie Von Weimar Bis Zur Deutschen Vereinigung, Darmstadt, Wiss. Buchg.

Lundqvist, L. J. (1986) Housing Policy and Equality. A Comparative Study of Tenure Conversions and Their Effects, London, Croom Helm.

Maddison-Project (2013) 'New Maddison Project Database', accessed at http://www.ggdc.net/ maddison/maddison-project/home.htm, 2013 version.

Manow, P. (2015) 'Workers, Farmers and Catholicism: A History of Political Class Coalitions and the South-European Welfare State Regime', Journal of European Social Policy, 25, 32-49.

Marx, K. (2007) Der Achtzehnte Brumaire Des Louis Bonaparte, Frankfurt a.M, Suhrkamp.

Mian, A. and Sufi, A. (2009) 'The Consequences of Mortgage Credit Expansion: Evidence from the U.S. Mortgage Default Crisis', The Quarterly Journal of Economics, 124, 1449-1496.

Misgeld, K. (2001) Socialdemokratins Program. 1897 till 1990, Stockholm: Socialdemokraterna \& Arbetarrörelsens arkiv och bibliotek.

Mommsen, W. (1960) Deutsche Parteiprogramme, München: Isar-Verl.

Norberg, J. (2009) Financial Fiasco. How America's Infatuation with Homeownership and Easy Money Created the Economic Crisis, Washington, DC, Cato Institute.

Norris, M. (2016) 'Varieties of Home Ownership: Ireland's Transition from a Socialised to a Marketised Policy Regime', Housing Studies, 31, 81-101.

NSD (2016) Data Om Det Politiske System. Partidokumentarkivet, Norsk Senter for Forskningsdata, Bergen, Norway, accessed at http://www.nsd.uib.no/polsys/data/parti/partido kumentarkivet/ on July 29, 2017.

Piccinato, G. (1988) 'Zum italienischen Volkswohnungsgesetz vom 31. Mai 1903. Entstehung des sozialen Wohnungsbaus in Italien 1896-1914'. In R-L., Juan and Gerhard, F. (eds) Die Kleinwohnungsfrage: Zu Den Ursprüngen Des Sozialen Wohnungsbaus in Europa, Hamburg, Christians, pp. 391-408.

Pilat, S. (2014) Reconstructing Italy. The Ina-Casa Neighborhoods of the Postwar Era, Farnham, Ashgate.

Pooley, C. G. (1992) 'Housing Strategies in Europe, 1880-1930: Towards a Comparative Perspective'. In Pooley, C. G. (ed.) Housing Strategies in Europe 1880-1930, Leicester: Leicester University Press, pp. 325-348.

Raymond, M.-G. (1966) La politique pavillonnaire, Paris, Institut de sociologie urbaine, Centre de recherche d'urbanisme.

Rünstler, G. (2016) 'How Distinct Are Financial Cycles from Business Cycles?', ECB Research Bulletin.

Ruonavaara, H. (1996) 'The Home Ideology and Housing Discourse in Finland 1900-1950', Housing Studies, 11, 89-104.

Schelkle, W. (2012) 'A Crisis of What? Mortgage Credit Markets and the Social Policy of Promoting Homeownership in the United States and in Europe', Politics \& Society, 40, 59-80.

Schulz, G. (1988) 'Eigenheimpolitik und Eigenheimförderung im ersten Jahrzehnt nach dem Zweiten Weltkrieg'. In Axel Schildt and Arnold Sywottek (eds) Massenwohnung Und 
Eigenheim. Wohnungsbau Und Wohnen in Der Großstadt Seit Dem Ersten Weltkrieg, Frankfurt/New York, Campus Verlag, pp. 409-439.

Seeger, H. R. T. (1995) Wohnungswirtschaft Im Wablzyklus Der Politik, Sinzheim, Pro Universitate Verlag.

SND (2017) 'Svensk Nationell Datatjänst', accessed date https://snd.gu.se/sv/vivill/by-year.

Sørvoll, J. (2013) The Politics of Cooperative Housing in Norway and Sweden 1960-1990 (1945-2013). The Swedish Deregulation of 1968 and the Norwegian Liberalization of the 1980s, Dissertation, Oslo.

Sowa, G. (1991) Die Wohnungsfrage in Paris 1853-1959. Politische, sozio-ökonomische und ideologische Aspekte der Wohnraumversorgung an der Seine von Napoleon III. bis de Gaulle, Pfaffenweiler: Centaurus-Verlagsgesellschaft.

Stieber, N. (1998) Housing Design and Society in Amsterdam. Reconfiguring Urban Order and Identity, 1900-1920, Chicago, IL, University of Chicago Press.

Streeck, W. (2013) Gekaufte Zeit. Die Vertagte Krise Des Demokratischen Kapitalismus, Frankfurt am Main, Campus.

Sveinsson, J. R. (2004) 'The formation of urban homeownership in Iceland', ENHR Conference, Cambridge, UK.

Treue, W. (1988) 'Ludwig Bentfeldt. Der Deutsche Bund Als Nationales Band 1815-1866. Göttingen: Musterschmidt. 1985. Pp. 498. DM 78', The American Historical Review, Deutsche Parteiprogramme 1861-1954, Göttingen, Musterschmidt.

Van Kersbergen, K. (1995) Social Capitalism. A Study of Christian Democracy and the Welfare State, London, Routledge.

Volkens, A., Lehmann, P., Matthieß, T., Merz, N., Regel, S. and Werner, A. (2015a) The Manifesto Data Collection, ed. Manifesto Project (MRG/CMP/MARPOR), Berlin, Wissenschaftszentrum Berlin für Sozialforschung (WZB).

Wooley, J. and Gerhard, P. (2016) 'The American Presidency Project', accessed at http://www.pres idency.ucsb.edu/platforms.php.

Zavisca, J. R. and Gerber, T. P. (2016) 'The Socioeconomic, Demographic, and Political Effects of Housing in Comparative Perspective', Annual Review of Sociology, 42, 347-367. 


\section{Appendix}

Table A1 Logistic regression on missing data

Missing manifesto

Manifesto length

$0.00003 *(0.00001)$

Vote share

$-0.005 * *(0.001)$

Number of parties

$0.0004(0.004)$

Period 1920-1955 (reference 1990-2006)

$0.231 * * *(0.028)$

Period 1956-1975

$0.068 *(0.023)$

$0.023(0.021)$

Period 1976-1990

$-0.111 * *(0.025)$

Australia (reference Germany)

$0.101 *(0.051)$

$0.053(0.055)$

Austria

Belgium

$-0.037(0.048)$

Canada

$-0.009(0.052)$

Denmark

$0.202 * *(0.046)$

Finland

$0.219 * *(0.048)$

France

$0.289 * *(0.050)$

$0.070(0.055)$

Ireland

$0.258 * *(0.050)$

Italy

$0.274 * *(0.048)$

$0.081(0.047)$

The Netherlands

$0.035(0.052)$

New Zealand

$-0.016(0.050)$

Norway

Portugal

$0.412 * *(0.051)$

Spain

$0.188 * *(0.054)$

$0.060(0.048)$

Sweden

$0.286 * *(0.048)$

$0.107(0.062)$

USA

$-0.083 *(0.029)$

Socialist parties

$-0.022(0.039)$

Ecological parties

$0.022(0.039)$

Liberal parties

$-0.004(0.026)$

$0.030(0.026)$

$0.052 *(0.025)$

Conservative parties

$0.088 *(0.042)$

Nationalist parties

$-0.064(0.037)$

Agrarian parties

$0.344 * *(0.038)$

$0.018(0.040)$

Special issue parties

$0.028(0.055)$

Constant

2,175

Observations

$-662.772$

Log likelihood

1395.543

Note: ${ }^{*} P<0.05 ;{ }^{*} P<0.01 ; * * * P<0.001$. 
Table A2 Logistic regression on housing mentions

\begin{tabular}{|c|c|c|c|}
\hline & \multicolumn{3}{|c|}{ Housing on manifesto agenda } \\
\hline & Model (1) & Model (2) & Model (3) \\
\hline Document length & $1.024 * * *(0.157)$ & $0.915 * * *(0.157)$ & $0.971 * *(0.154)$ \\
\hline Left-right (RILE) & $-0.188 *(0.085)$ & $-0.121(0.082)$ & $-0.157(0.086)$ \\
\hline Vote share & $0.198 *(0.100)$ & $0.216^{*}(0.101)$ & $0.189(0.103)$ \\
\hline Homeownership & $0.265(0.238)$ & & \\
\hline House prices & $0.298(0.165)$ & & \\
\hline GDP p.c. & $-0.608 *(0.270)$ & & \\
\hline Party competition & & $0.627(0.514)$ & \\
\hline Lag incumbency & & $0.040(0.078)$ & \\
\hline GDP p.c. growth rate & & & $-0.0005(0.103)$ \\
\hline Homeownership growth & & & $0.184 *(0.075)$ \\
\hline House price growth & & & $0.044(0.077)$ \\
\hline $\begin{array}{l}\text { Period } 1920-1955 \text { (reference } \\
\quad \text { period 1991-2006) }\end{array}$ & $-0.324(0.622)$ & $0.667 *(0.283)$ & $0.244(0.319)$ \\
\hline Period 1956-1975 & $0.530(0.419)$ & $0.905 * *(0.196)$ & $0.921 * * *(0.219)$ \\
\hline Period 1976-1990 & $0.410(0.254)$ & $0.595 *(0.187)$ & $0.533 *(0.197)$ \\
\hline Period 2007-2015 & $-0.081(0.268)$ & $-0.123(0.233)$ & $-0.072(0.226)$ \\
\hline Socialist parties & $0.423(0.295)$ & $0.476(0.291)$ & $0.401(0.299)$ \\
\hline Ecological parties & $-1.099 * * *(0.332)$ & $-1.018 *(0.337)$ & $-1.051 *(0.333)$ \\
\hline Liberal parties & $-0.394(0.245)$ & $-0.437(0.251)$ & $-0.412(0.248)$ \\
\hline Christian democratic parties & $-0.134(0.273)$ & $-0.337(0.273)$ & $-0.267(0.276)$ \\
\hline Conservative parties & $-0.104(0.267)$ & $-0.361(0.275)$ & $-0.081(0.271)$ \\
\hline Nationalist parties & $-0.703(0.411)$ & $-0.875 *(0.378)$ & $-0.829 *(0.416)$ \\
\hline Agrarian parties & $-0.489(0.314)$ & $-0.549(0.316)$ & $-0.510(0.318)$ \\
\hline Ethnic and regional parties & $-1.194 *(0.391)$ & $-1.437 * * *(0.425)$ & $-1.248 *(0.394)$ \\
\hline Special issue parties & $0.003(0.397)$ & $0.260(0.415)$ & $-0.083(0.401)$ \\
\hline Constant & $2.147 * * *(0.520)$ & $1.419 * * *(0.316)$ & $1.397 * *(0.404)$ \\
\hline Observations & 1636 & 1615 & 1589 \\
\hline Fixed effects & Countries & Countries & Countries \\
\hline Log Likelihood & -715.412 & -709.841 & -696.156 \\
\hline Akaike information criteria & 1506.823 & 1489.682 & 1468.312 \\
\hline
\end{tabular}

Note: ${ }^{*} P<0.05 ; * P<0.01 ; * * P<0.001$. 
Table A3 Logistic regression on pro-homeownership positions

Pro-homeownership manifestos

(1) (2) (3) (4)

\begin{tabular}{|c|c|c|c|c|}
\hline Document length & $0.376 * *(0.112)$ & $0.350 *(0.122)$ & $0.301 *(0.124)$ & $0.340 *(0.125)$ \\
\hline Left-right (RILE) & $0.146(0.103)$ & $0.143(0.114)$ & $0.134(0.114)$ & $0.185(0.115)$ \\
\hline $\begin{array}{l}\text { Period 1920-1955 } \\
\quad \text { (reference period } \\
\text { 1991-2006) }\end{array}$ & $-0.782 *(0.297)$ & $-0.958 *(0.339)$ & $-0.970(0.764)$ & $-0.996 *(0.398)$ \\
\hline Period 1956-1975 & $-0.172(0.240)$ & $-0.362(0.255)$ & $-0.319(0.528)$ & $-0.230(0.274)$ \\
\hline Period 1976-1990 & $0.427(0.240)$ & $0.378(0.252)$ & $0.349(0.338)$ & $0.427(0.261)$ \\
\hline Period 2007-2015 & $-0.802 *(0.272)$ & $-0.968 *(0.306)$ & $-0.696 *(0.327)$ & $-0.749 *(0.293)$ \\
\hline Lag incumbency & & $0.059(0.098)$ & & \\
\hline Vote share & & $0.232(0.127)$ & $0.302 *(0.124)$ & $0.330 *(0.128)$ \\
\hline Party competition & & $-6.160(3.782)$ & $-0.150(0.599)$ & $0.545(0.459)$ \\
\hline Homeownership & & & $0.640 *(0.304)$ & \\
\hline House prices & & & $0.138(0.192)$ & \\
\hline GDP p.c. & & & $-0.457(0.312)$ & \\
\hline Homeownership growth & & & & $-0.046(0.086)$ \\
\hline House price growth & & & & $-0.084(0.091)$ \\
\hline GDP growth & & & & $0.072(0.128)$ \\
\hline $\begin{array}{l}\text { Socialist parties } \\
\qquad \begin{array}{l}\text { (reference social } \\
\text { democratic parties) }\end{array}\end{array}$ & $-0.971 * * *(0.250)$ & $-0.616^{*}(0.293)$ & $-0.850 * *(0.296)$ & $-0.795 *(0.301)$ \\
\hline Ecological parties & $-3.173 * * *(0.525)$ & $-3.042 * * *(0.598)$ & $-3.256^{* * *}(0.628)$ & $-3.270 * * * 0.638)$ \\
\hline Liberal parties & $0.839 * *(0.268)$ & $1.147 * * *(0.301)$ & $0.999 * * *(0.296)$ & $0.924 *(0.299)$ \\
\hline Christian democratic parties & $2.104 * * *(0.352)$ & $2.231 * * *(0.376)$ & $2.058 * * *(0.376)$ & $1.815 * *(0.375)$ \\
\hline Conservative parties & $1.522 * * *(0.354)$ & $1.924 * * *(0.426)$ & $1.481 * * *(0.371)$ & $1.338 * *(0.374)$ \\
\hline Nationalist parties & $0.969(0.506)$ & $1.353 *(0.542)$ & $1.465 *(0.673)$ & $1.296(0.665)$ \\
\hline Agrarian parties & $1.203 * *(0.431)$ & $1.432 *(0.452)$ & $1.251 *(0.455)$ & $1.058 *(0.454)$ \\
\hline Ethnic and regional parties & $0.431(0.457)$ & $0.765(0.521)$ & $0.727(0.492)$ & $0.663(0.489)$ \\
\hline Special issue parties & $0.500(0.395)$ & $0.924 *(0.465)$ & $0.581(0.442)$ & $0.452(0.448)$ \\
\hline Constant & $0.494(0.360)$ & $-3.482(2.289)$ & $1.352 *(0.504)$ & $0.653(0.380)$ \\
\hline Observations & 1371 & 1240 & 1244 & 1207 \\
\hline Fixed effects & Countries & Countries & Countries & Countries \\
\hline Log Likelihood & -547.893 & -480.740 & -487.977 & -475.947 \\
\hline Akaike information criteria & 1163.786 & 1031.479 & 1051.954 & 1027.895 \\
\hline
\end{tabular}

Note: ${ }^{*} P<0.05 ; * P<0.01 ; * * P<0.001$. 